\title{
Improving Local Community Knowledge and Skills in Homestay Management
}

\author{
Hendri Azwar ${ }^{1}$, Sukma Yudistira $^{1(*)}$, Eval Edmizal $^{2}$ \\ ${ }^{I}$ Dep. of Tourism, Faculty of Tourism and Hospitality, Universitas Negeri Padang, Padang, Indonesia \\ ${ }^{2}$ Faculty of Sport Sciences, Universitas Negeri Padang, Padang, Indonesia \\ "Corresponding author. Email: sukma.yudistira@fpp.unp.ac.id
}

\begin{abstract}
Nagari Tabek Panjang is one of Nagari (local government), which has several attractions located in Kecamatan Baso, Kabupaten Agam. One of them is the Ikan Sakti Sungai Janiah attraction. This attraction lacks tourist facilities for lodging in the form of Homestay. This can be developed by utilizing local community houses and traditional houses in the tourist attraction environment. However, local people do not yet understand how to prepare and manage Homestay that meet the standards. Collaboration between the University and the community is expected to provide a solution to the Improvement of Local Community Knowledge and Skills in Managing Homestay. The purpose of community service activities was to facilitate and help the community in terms of the problem faced. The form of activities that have been carried out is providing training on Homestay management, helping to identify and analyze a proper community house into a Homestay, making a pilot Homestay, and registering a Homestay brand. Besides, training on makeup room and Homestay promotion was also carried out through the Nagari web built by Universitas Negeri Padang and Homestay brochure.
\end{abstract}

\section{Keywords: Local Communities, Management, Homestay, Attractions}

\section{INTRODUCTION}

The tourism sector is one of the mainstay sectors to improve the regional economy. This can be seen from the many developments and developments in the tourism industry in various regions. UNWTO explained that Tourism comprises the activities of persons traveling to and staying in places outside their usual environment for not more than one consecutive year for leisure, business, and other purposes. Activities Tourism interaction will occur between tourists, business service providers, the government, and the local community in providing services to tourists to improve the people's economy.

Tourism is an economic symptom because there is a demand from tourists and offers from tourism service providers (travel agencies, lodging, and restaurants) for products and various related facilities (Sulastiyono, 2011). Tourist support facilities that must be available at a tourism destination are lodging. Lodging is a facility provided for tourists with the aim of tourists staying longer in tourist destinations. One lodging that can be provided at tourist destinations is a Homestay.

A Homestay is a part of a house that is rented out to guests for a while to learn the culture of the local community (Prihartini, 2017). The building utilizes community houses and is directly managed by the community so that tourists can see directly and learn about lives people's and are managed by the community.
Therefore, knowledge is needed for the community in managing Homestay with a Community Based Tourism (CBT) system so that it can provide satisfaction for tourists.

Community-Based Tourism (CBT),, which is one of the approach bottoms up in the form of policies, shows the challenges and opportunities for the community to work with the public and private sectors (Theerapappisit, 2012). Understanding of community-based tourism is very closely related to local economic development because it not only discusses tourism as a sectoral element but also discusses empowerment, where the empowerment of all stakeholders involved, especially the local community. Besides, it can increase the ability of local communities to create better products and industrial development and tourism business activities on a local scale.

One area that is a tourist destination that will be developed in Agam Regency is Nagari Tabek Panjang. Nagari is located in Baso District, geographically Nagari Tabek Panjang is between $0^{\circ}$ - 3o South Latitude, 100.28 ${ }^{\circ}$ East, with an area of $19.19 \mathrm{KM} 2$ at an altitude of 800 $900 \mathrm{~m}$ above sea level. Judging from its potential, Sungai in Nagari Tabek Panjang has the opportunity to be developed as a transit, tourism, and trade and agriculture area. This is due to its strategic position as the area Hitterland Agropolitan of Agam Regency and across the triangles Payakumbuh, Batusangkar, and Bukittinggi. 
Nagari Tabek Panjang has one of the leading attractions, namely the Ikan Sakti Sungai Janiah which is natural tourism in the form of a pond containing fish that is protected by the community. Based on the legend the fish is believed by residents around to come from a pair of humans. Besides the Ikan Sakti Sungai Janiah, there is also a hill that reaches \pm 800 meters above sea level named Batanjua Hill which has a diversity of flora and fauna and beautiful natural scenery. Besides that, Batanjua Hill is unique in that it has a spring in a rock that can be drunk and is never dry even during the dry season. Based on the belief of the local people, the water can be a cure for various diseases (Azwar, 2017).

In the attraction of Ikan Sakti Sungai Janiah, the buildings around the tourist attraction are still maintained its authenticity to provide a genuine atmosphere of Minangkabau. Besides that, the view of the Batanjua Hill and its trees shady gives an exciting natural feel and has the potential to be developed in various tourism activities in the Sakti Ikan Sakti Sungai Janiah Attraction. The following is the documentation of the location of the Ikan Sakti Sungai Janiah

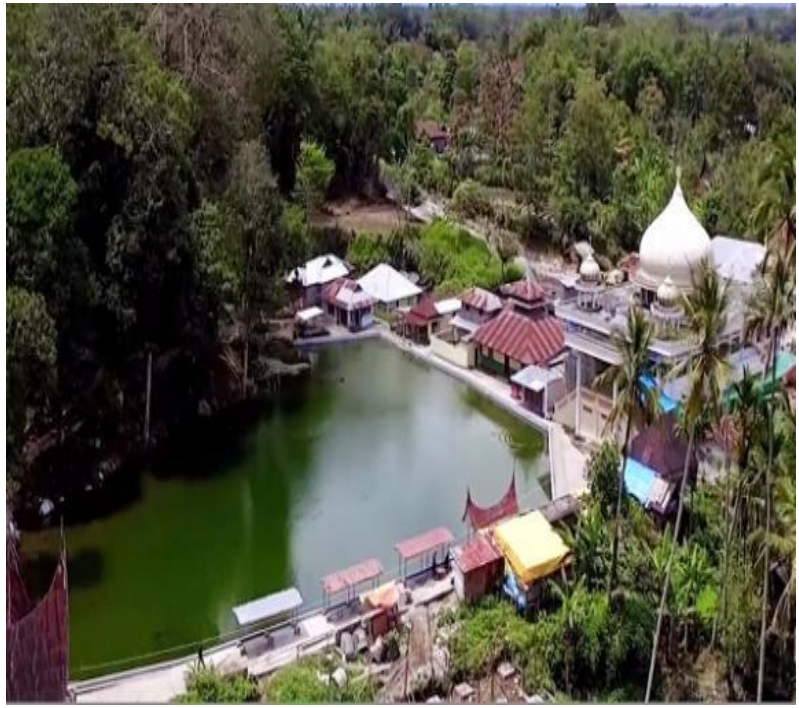

Figure 1. Objects

Based on the picture above shows the natural beauty of the Ikan Sakti Sungai Janiah attraction, where the buildings around the tourist attraction are still maintained its authenticity to provide the original atmosphere of Minangkabau. Besides that, the view of the Batanjua Hill and its trees shady provide a fascinating natural nuance and has the potential to be developed in various tourism activities in the Ikan Sakti Sungai Janiah attraction. Furthermore, from direct observation to tourism objects, one that has the potential to be developed is a Homestay for tourists. This was developed by utilizing the houses of residents and traditional houses by identifying in advance the appropriate homes to be Homestay according to their standards. Thus tourists can learn firsthand the culture of the local community. Besides that, the strategic location of the area and located on the trans-Sumatra road is a factor driving the development of Homestay in the area.

Universitas Negeri Padang State in 2018 has been devoted to the community at the Ikan Sakti Sungai Janiah attraction. In this service, the community received training on managing tourist attractions at the Ikan Sakti Janiah attraction. Furthermore, based on discussions with tourism conscious groups (Pokdarwis) for floating attraction further additional tourism facilities are needed to increase tourist visits. One of them is making lodging in the form of a Homestay. This is supported by the number of houses that are not inhabited as well as traditional houses that have the potential to become Homestay. To realize the Homestay requires the knowledge and skills of the local community as a provider of Homestay services later.

The problem of the absence of Homestay and the lack of partner knowledge will undoubtedly hamper the economic development process in the partner area and Nagari Tabek Panjang in general. The cooperation between universities and the community is expected to provide solutions to the management and development of the Ikan Sakti Sungai Janiah tourism object.

The solution to the problem that will be given by the community service team of Universitas Negeri Padang is to provide training to improve the knowledge and skills of local communities in management Homestay in the Kanagarian Tabek Panjang, Kecamatan Baso, and Kabupaten Agam by the expertise of the dedicated team. Then help identify suitable community homes into a Homestay. Furthermore, it was assisting in making the name of a pilot Homestay in the Ikan Sakti Sungai Janiah Attraction. The materials that will be provided during training as a solution to the problems faced by partners are as follows:

1. Training on the type of accommodation; in this material will be explained about the type of accommodation in general, the scope and classification of Homestay, and the importance of developing Homestay as supporting tourism.

2. Homestay Management Training; the proposing team will provide training to improve the knowledge and skills of local communities in management. Homestay

3. Practices in identifying and analyzing local community houses that meet the Homestay classification

4. . Assistance provided by the dedicated team is for the manufacture of signboards, brochures, and the completeness of supporting making beds for the pilot Homestay at the Ikan Sakti Sungai Janiah Attraction.

5. Makeup Room Training and Homestay Promotion; these training participants are trained to make beds according to standards; local people are directed in making attractive promotions using social media. Then the promotion through the Nagari web built by Universitas Negeri Padang in the Ikan Sakti Sungai Janiah Attraction Sakti and the making of a pilot Homestay brochure.

6. Arrangement of Homestay name registration; this arrangement is made to register the name of the Homestay to the official tourism so that the Homestay can operate and be promoted online. Homestay name registration is done for 1 pilot Homestay in the area. 


\section{METHODS}

The implementation of community service is carried out in collaboration with partners and uses several methods. The method of implementation is as follows: Analysis of community conditions

To achieve the ideal conditions, an analysis of the conditions of the community around the service area is needed. The first thing to do is to map the characteristics of the local community. After that, determine some places that can be used as Homestay development. Its development is focused on houses that are closer to the Sakti Ikan Sakti Sungai Janiah Attraction. In analyzing the condition of this community will produce data about community homes that have the potential to be developed into a Homestay.

Implementation of training programs

This method is used to improve the knowledge and skills of local communities in managing Homestay in the form of lectures, questions, and answers and on training hands-. The material to be presented is: 1) Knowledge of the importance of Homestay in supporting tourism. 2) Criteria for the establishment of Homestay in attractions and Homestay management. 3) Simulations in identifying local community homes that meet the classification of Homestay. 4) Makeup Room and Homestay Promotion. Training the participants were trained to make beds according to standards, the local community was directed in making attractive promotions using social media. Then the promotion was through the Nagari web built by Universitas Negeri Padang in the Ikan Sakti Sungai Janiah Attraction and the making of a pilot Homestay brochure.

Making Homestay signage

Proposers assist with purchasing materials for the manufacture of Homestay pilot signage. Before making the nameplate does cooperation with the community first in cleaning the house that has the potential to become a pilot Homestay. Then the servant helps register the name of the pilot Homestay to the Department of Tourism so it can be promoted directly or online.

Method of demonstration and assignment

This method of local communities will be divided into groups and then assigned to identify homes that are suitable to be Homestay. After that the community and community service team together in making the management of the Homestay management by forming a working system in the management of a Homestay. After that, the community will apply it to the house that has been set.

\section{Guidance}

Guidance is carried out related to Homestay management and development activities in Nagari Tabek Panjang. The Dedication Team conducts guidance, starting from identifying the potential houses to be used as Homestay to the management carried out by the local community. It is intended that the knowledge and skills acquired by the community are by the same qualifications in each Homestay that will be developed primarily in the environment of the Ikan Sakti Sungai Janiah attraction.

\section{RESULTS AND DISCUSSION}

The first activity is a joint discussion between the community service team and the community who will attend the training. This discussion discusses plans for the preparation of community service activities such as the formation of groups in the implementation of training, the appointment of a group leader, planning and designation of one house as a pilot Homestay, and preparation for the next service activities. The activity is as described below:

Training on Accommodation and Knowledge Homestay a Tourism Support

In this material, the types of accommodation in general and their scope are explained, then discuss more specifically about Homestay and their classification. The purpose of this training is the community knows the importance of Homestay as a supporter of tourism as well as a new economy among the people. The benefit of this training is that the community can understand the type of accommodation, primarily Homestay so that they can prepare potential homes to become Homestay that are by the standards.

Knowledge and Skills Enhancement Training for Local Communities in the Management of Homestay

In this material, it is explained how to manage people's homes according to standards into a Homestay. The purpose of this training is that the community has increased knowledge and skills in managing Homestay. The benefits of this training are that the community can directly manage their house to become a Homestay after completing the needs and completeness of the Homestay and is feasible to be marketed to tourists.

Preparing a House to Become a Pilot Homestay

After conducting further training, the service team and the community check the condition of the completeness of the house, which will be used as a pilot Homestay. The Homestay will be used as a reference or community guide to make a potential home a Homestay. This activity of the service team explained what completeness of the house was by the standard and that was not following the Homestay standard, starting from the completeness of the room, bathroom, living room, kitchen and other facilities to support the realization of a Homestay that was according to the standard. Then the Homestay trademark registration is carried out under the name Batanjua Homestay which is used as a pilot. Documentation

\section{CONCLUSIONS}

The implementation of community service is carried out in collaboration with partners and uses several methods. Implementation under the order of establishment of a Homestay can provide understanding to the community in identifying, determining, and creating a Homestay that is appropriate to the minimum requirements. Coupled with the Homestay pilot, it can provide concrete examples of the Homestay viable and also be able to observe directly the use, maintenance, cleaning, and its settings. This achievement can have a significant impact on presenting alternative economic 
sources that have good potential for the community. It is expected that with this achievement, the community can improve their economy and maximize the potential of the attractions and tourists they have.

\section{ACKNOWLEDGMENTS}

Thank you to the LP2M of Universitas Negeri Padang for funding this dedication, the Government of Agam regency, especially the Baso sub-district head, walinagari Tabek Panjang, and the community around the attraction of the Sungai Janiah.

\section{REFERENCES}

[1] Azwar, Hendri. 2017. Potensi Pengembangan Daya Tarik Wisata Di Destinasi Pariwisata Ikan Sakti Sungai Janiah Kecamatan Baso Kabupaten Agam.Jurnal Pendidikan dan Keluarga. [S.1.], v. 9, n. 1, p. 54-67, June 2017. ISSN 2549-9823. DOI: https://doi.org/10.24036/jpk/vol9-iss 1/45

[2] Prihartini, Nunung. 2017. Homestay dan Ekowisata sawahan Dengan pendekatan arsitekktur organik di Kaliurang. FTUniversitas Atma Jaya Yogyakarta

[3] Sulastiyono, Agus. 2011. Manajemen Penyelenggaraan Hotel. Bandung: Alfabeta

[4] Theerapappisit, Polladach. 2012. The BottomUp Approach of Community-Based EthnicTourism: A Case Study in Chiang Rai. School of Social Sciences and Psychology, University of Western Sydney, Australia. Intech Journal Strategies for Tourism Industry - Micro and Macro Perspectives Published in print edition April, 2012 